\title{
The Role of the Federal Reserve iN RESERVE REQUIREMENT REGULATION Mark Toma
}

Traditionally, economists have highlighted the macroeconomic consequences of reserve requirement regulation. A public-spirited central bank may impose reserve requirements to increase its control over the money supply. For a given money multiplier, the monetary authority controls the money supply through its production of reserves. Although the money multiplier may change over time, its variability decreases as the reserve requirement approaches one.

The traditional approach ignores the possibility that banks may be able to evade reserve requirement regulations by providing customers with nonreservable deposits. To enforce reserve requirement regulations, resources must be employed by some government agency. The enforcement authority may be a local agency or the central bank itself. For example, before 1980 a U.S. bank's choice of state agency or Federal Reserve System membership determined which authority would set and enforce reserve requirements. Edward Kane (1982) suggested that the ability of banks to choose their regulator constrained the Fed and state agencies to reduce reserve requirements to the "market" level. Kane's conclusion seems inconsistent with the traditional prediction that a central bank sets a high reserve requirement for monetary control reasons.

This paper attempts to explain the reserve requirement decisions of real world central banks by developing competitive and monopoly models of reserve requirement regulation. In the competitive model, local regulatory agencies compete with the central bank in setting and enforcing reserve requirements. After defining Kane's market reserve requirement, I specify the circumstances under which competition reduces the reserve requirement to this level.

Cato Journal, Vol. 7, No. 3 (Winter 1988). Copyright 0 Cato Institute. All rights reserved.

The author is Associate Professor of Economics at Miami University in Ohio. 
I then modify the regulatory model along the lines suggested by the Depository Institutions Deregulation and Monetary Control Act of 1980. This act deregulated deposit interest rates in the United States and transformed the process of setting reserve requirements from a competitive one to a monopolistic one. For the first time, the Fed could set and enforce reserve requirements for all financial institutions that offered transaction accounts.

To contrast how a central bank sets reserve requirements under competitive and monopolistic conditions, I assume that the revenue consequences of money production motivate central bankers. Such an assumption may not be very useful in explaining the day-to-day actions of central bank decision makers, but it seems appropriate when viewing the Monetary Control Act as a change in the nation's monetary constitution. I argue that the act eliminated a constraint on the Fed's actions, and thereby enhanced its ability in the long run to raise revenue through money creation. Overall, the analysis suggests that changes in the incentives facing central bank decision makors, and not macroeconomic issues, determine long-run reserve requirement policy.

\section{A History of Reserve Requirement Enforcement}

The 1935 Banking Act gave the Federal Reserve System statutory authority to specify the amount of reserves banks were required to hold behind their deposits. This power, however, was not absolute because the Fed could impose reserve requirements only on deposits of its member banks. State agencies set requirements for other banks.

Although Fed member banks faced a set of reserve requirements that did not depend on their locational decision, before 1980 the requirements of nonmember institutions varied from state to state. Most state regulatory agoneies imposed statutory requirements that were lower than Fed-mandated requirements (Gilbert and Lovati 1978). State agencies also were more lenient in what they defined as reserves. They generally allowed their members to count deposits at approved banks as reserves and often allowed government securities and cash items in process of collection to be counted as well. A few state agencies imposed no requirements. The relative leniency of state-imposed reserve requirements was a primary reason for the membership decline at the Fed after World War II. Responding to this decline, in 1959 the Fed allowed its members to count as reserves vault cash in addition to deposits at the Fed. ${ }^{1}$

'See Goodfriend and Hargraves (1982) for a description of how the required reserve definition has changed over time. 
Before 1980, a bank's decision to transfer membership from the Fed to a state agency affected the demand for Fed-produced reserves. Given generally lower state requirements, the membership change directly reduced aggregate (Fed member bank and other bank) reserve holdings. But even if aggregate reserve holdings did not change, the demand for Fed reserves would fall because state banks could satisfy requirements by holding assets (such as government securities) that were not produced by the Fed.

Banks' ability to evade reserve requirement regulations imposed another limitation on the regulatory powers of the Fed. Statutory authority to set reserve requirements has no practical implications if the Fed does not devote resources to enforcing reserve requirement regulations. The Fed has two margins along which it can change the intensity of enforcement. First, it monitors member bank liabilities that already are officially defined as reservable. If reserve holdings are found to be insufficient at prespecified intervals, then legal sanctions are imposed on the negligent bank.

Second, the Fed monitors the creation by member banks of new liabilities that initially lie outside the reserve classification. Through such activity, the Fed intends eventually to bring these immovations within its regulatory umbrelia. Failure to act along either of the two enforcement margins would induce banks to hold no reserves behind accounts that legally are classified as deposits and/or to develop new liabilities that do not fall under reserve law as presently defined.

Recent advances in financial sector communications and information technology have made it more profitable for banks to produce nonreservable deposit-like accounts (Kane 1981a, Greenbaum 1983, Hester 1981). For example, commercial paper issued by a bank's parent holding company in the late 1960s was not treated as a deposit under the law. The holding company could issue the paper as a nonreservable liability and then distribute the funds to the subsidiary bank.

Also, with development of electronic wire transfer technology, large banks in 1968 began acquiring funds through repurchase agreements. Banks sold securities to corporate customers at the close of a business day and simultaneously agreed to repurchase the securities at the beginning of the next day. This transaction was attractive to banks because funds acquired through these agreements had no reserve requirements.

The markets for bank commercial paper and repurchase agreements expanded rapidly in the late 1960 s and early 1970 s. In response, the Fed worked to modify reserve law so that these bank liabilities would be treated as reservable deposits. On September 18, 1970, 
after only a year of regulatory deliberations, the Fed amended Regulation $\mathrm{D}$ on member bank reserve requirements to cover commercial paper sales by bank holding companies and their subsidiaries when the proceeds were used to supply funds to bank affiliates. In contrast, the banking sector was able to deflect the Fed's attempt to impose requirements on repurchase agreements.

Several factors affected the uneven pace of defining new bank liabilities as reservable. Banks, themselves, could influence the classification process by lobbying the Fed to ignore the innovations. The intensity of bank lobbying tended to reflect how closely the innovation substituted for simple deposit accounts. Innovations that were identical to deposits, except in name, would be relatively valuable to bank customers and would foster much bank lobbying.

Differential enforcement costs also affected the pace of regulation. The higher the costs of detecting a particular type of bank liability for reserve requirement purposes, the longer the lag between innovation and regulation. Finally, the Fed had to contend with the possibility that some state banking agency enforcement levels were more stringent than others. If an innovation originated in a state with relatively lenient enforcement, then the Fed would risk losing members in that state if it quickly imposed reserve requirements.

Just as the reserve requirements set by the Fed tended to be higher than state requirements, Fed enforcement efforts appeared to be more thorough than many state efforts (Gilbert and Lovati 1978). In general, state banking agencies devoted few resources to discovering and punishing those banks that failed to back reservable deposits. They also tended to be relatively tolerant of financial innovations designed to circumvent state regulations.

The 1980 Monetary Control Act strengthened the Fed's position in the regulatory hierarchy by expanding its power to impose reserve requirements (within certain statutory limits) not only on member banks of the Federal Reserve but also on nonmember depository institutions. These requirements covered transaction accounts, nonpersonal time deposits, and Eurodollar borrowings. While lowering the reserve requirements faced by Fed member banks, the act raised the requirements for other banks by enough to increase the overall reserve burden (Cacy and Winningham 1982).

Members of the Fed can satisfy the new requirements by holding vault cash and/or deposits at Federal Reserve Banks. Other financial institutions have additional pass-through options. Nonmember state banks, for example, can hold reserves in the form of deposits at designated institutions having accounts directly with the Fed. These designated institutions must hold vault cash or Fed deposits on a 
dollar-for-dollar basis behind their deposits from nonmember banks. Because of the pass-through option, every dollar of reserves held by nonmembers of the Fed increases the Fed's reserves by that full dollar. ${ }^{2}$

Under the Monetary Control Act, the Fed became a monopolist both in setting and enforcing reserve requirements. The act, for the first time, required all depository institutions periodically to report their deposit liabilities and reserves to the Fed. State agencies no longer were directly responsible for monitoring whether their members observed reserve requirement regulations.

\section{The Market for Reserve Requirement Regulation}

Any serious theory of reserve requirement regulation must generate predictions that are consistent with the history outlined in the previous section. At the very least, a theory should (1) define the socalled market reserve requirement and specify the circumstances when the actual requirement will be at or above this benchmark level, (2) explain why reserve requirements and enforcement activities in the United States varied across states before 1980 and why they tended to be higher with Fed membership, and (3) predict how the Monetary Control Act will affect the overall reserve-to-deposit ratio.

Identifying the objective function of the regulators and the constraints they face is a first step in developing a testable theory. Consider the objective function of the primary regulator of reserve requirements-the central bank. The long-run tendencies of the central bank as a money producer may be highlighted by assuming it manipulates its production rate along with the reserve requirement to maximize revenue for the government.

The annual revenue flow (seigniorage) equals the real amount of non-interest-bearing liabilities (the monetary base) produced by the central bank. To focus the analysis on reserve requirement regulation, I ignore the public's currency holdings and assume the private sector demands the central bank's monetary base only because it must be held by banks to satisfy reserve requirements on bank deposits. Also, deposits pay no interest and the base rate of production

\footnotetext{
${ }^{2}$ Before 1980 , a state bank might use correspondent balances as reserves. A dollar in state bank deposits increased correspondent balances by that dollar times the state requirement. Fed reserves increased by only the correspondent balance change times the Fed requirement.
} 


\section{Cato JOURNAL}

equals the inflation rate. These simplifying assumptions imply that seigniorage ( $\mathrm{S}$ ) equals

$$
S=\Delta H=\pi H=\pi k D(i)
$$

where $H$ is the real base, $\pi$ is the inflation rate, $k$ is the reserve requirement on real deposits, $D$, and $i$ is the nominal interest rate on bonds. Equation (1) indicates that the public's real deposit holdings are a function of the nominal bond rate.

According to this standard formulation, the reserve requirement does not influence deposit demand. ${ }^{3}$ Therefore, a seigniorage-maximizing central bank always benefits from increasing the requirement. If there are no political constraints, it sets the reserve requirement at one. Otherwise, the central bank raises the requirement as high as politically feasible and then selects the inflation rate that maximizes seigniorage. Viewing the reserve requirement as preset, Milton Friedman's (1953) well-known solution to this problem requires that the inflation rate be raised to the point where the inflation rate elasticity of base money demand equals a minus one.

The traditional approach makes a number of extreme assumptions about the nature of the regulatory market. Implicitly, it assumes that all banks choose central bank membership, or at least that both member and nonmember banks must back all of their deposits with central bank base. Furthermore, the traditional approach assumes the central bank devotes no resources to enforcing reserve requirement regulations. It is as if an automaton-like regulatory agency costlessly identifies and labels all bank money as deposits, subject to the prespecified reserve requirement. More generally, the seigniorage function should take into account that not all banks are required to hold reserves produced by the central bank, and those banks that are so required will comply with statutory requirements only if the central bank monitors their behavior.

To illustrate, consider two classes of banks. The law requires that central bank base support all the liabilities of class 1 banks. Class 2 banks fall outside the regulatory scope of the central bank, and therefore they do not hold central bank base. If $z$ is the percent of total financial sector liabilities that the central bank legally can require be backed by its base (that is, $z$ is the ratio of class 1 deposit liabilities to total deposit liabilities), then, with foolproof enforcement, the central bank can impose reserve requirements on $z D$ of total deposits.

\footnotetext{
'A more general formulation allows banks to pay interest on deposits. As Dwyer and Saving (1986) showed, reserve requirements then influence deposit demand.
} 
With less than perfect enforcement, only a fraction, $b$, of $z D$ will be detected for reserve requirement purposes.

Defining $b$ as the enforcement (detection) ratio, the traditional seigniorage function can be reformulated as

$$
S=\pi[b k+(I-b) \hat{k}] z D(i)-C(a) .
$$

The cost to the central bank of enforcing its reserve requirement is $C$, and $a$ represents units of the enforcement input used by the central bank to increase $b$. The symbol $\hat{k}$ represents the amount of (central bank) reserves class 1 banks voluntarily would hold behind a dollar of deposits even if the central bank did not enforce reserve requirements.

I interpret $\hat{k}$ as Kane's market reserve requirement. Without enforcement $\langle b=0), \hat{k}$ is the effective reserve requirement for class 1 banks. With foolproof enforcement $(b=1)$, the effective requirement becomes the central bank's statutory requirement, $k$. With partial enforcement, the effective reserve requirement is a weighted average, $b k+(I-b) \hat{k}$, of the statutory and market requirements. The central bank can change the effective reserve ratio either directly through an increase in the statutory reserve requirement, or indirectly by increasing $a$ and thereby the enforcement ratio, $b$.

Given the reformulated seigniorage equation, a complete theory of reserve requirement regulation requires specifying the constraints facing the central agency. Kane (1981b, p. 132) indicates three sets of constraints that should be considered in modeling the operation of a regulatory market: "distributive politics that define a clientele to be serviced and place statutory limits on an agency's authority, opportunities for regulatee avoidance activity, and action undertaken by competing regulators."

With respect to reserve requirement regulations, local (state) regulatory agencies may compete with the central (bank) agency. A second group of participants in the regulatory market are the financial institutions that serve as the central bank's regulatees. Finally, Kane's reference to "distributive politics" suggests that a federal government and a network of local governments play at least some role in overseeing the operation of the central and local regulatory agencies.

I assume these groups interact within a federal region that is divided into $n$ identical local jurisdictions. The local government in each region competes with other local governments in attracting financial institutions to its jurisdiction. Each of the $n$ local governments establishes a regulatory agency that offers charters to financial institutions that choose to locate in the region. By choosing the local charter, banks automatically become members of the local banking agency 


\section{Cato Journal}

and are bound by its regulations. ${ }^{4}$ Alternatively, any bank may select central bank membership and regulation by choosing a central charter.

Only one local regulatory body regulates banks in a region at any one time. However, I model entry into the local regulatory market as contestable. A potential local regulator can replace the existing regulator in a jurisdiction at zero cost.

Having specified the structure of the regulatory market, the constraints faced by the central regulatory agency depend on the objective functions of the other actors in the regulatory market. Consider the objective function of competing local regulatory agencies. Unlike the central banking agency, local agencies do not have the right to produce monetary base. Without this revenue source, local agencies rely on budget appropriations from their local government each period. ${ }^{5}$ Although not crucial to the analysis, for concreteness assume that agency employees want to maximize "excess" budgetary funds so as to engage in expense-preference behavior.

The actions of each local regulatory agency will be influenced by the preferences of its sponsor and its financial institution members. Initially, I make a simple assumption about the objective function of the sponsoring government. Each local government wants to maximize its local tax base in the form of total bank assets. Assuming homogeneous banks, the local government allocates budgets to its local agency so as to maximize the number of banks that choose to locate in the jurisdiction.

Finally, I assume that each financial institution confronts a dualchoice problem. Not only must it select a jurisdiction but, it also must decide whether to be a member of the local agency in that jurisdiction or the central agency. A representative bank will choose the regulatory agency that offers the most profits. When a bank receives the same profits with either agency, I assume the bank flips a coin to solve its membership problem.

To specify bank profits, assume that financial institutions have only non-interest-bearing transaction accounts as liabilities. Their assets consist of loans and reserves, and they always prefer to hold no excess reserves. Leaving aside intermediation costs, bank profits equal the revenue from loaning excess reserves on the market less any expenditures incurred in avoiding reserve requirement regulations. ${ }^{6}$

\footnotetext{
${ }^{4}$ In the United States, bank selection of a state charter does not preclude Federal Reserve membership.

${ }^{5}$ Some state agencies also receive a fee from the banks they inspect.

${ }^{\theta}$ This bank profit definition ignores bank entry into the market over time. It also assumes that banks compete for deposits on neither a pecuniary nor a nonpecuniary basis. Finally, the definition assumes that banks use no resources in acquiring a charter.
} 
When a regulatory agency raises the effective reserve requirement, outstanding loans and therefore bank profits fall. Banks can react to this regulatory burden by varying the amount of resources used to hide or shelter their deposits from the regulator. The enforcement ratio, $b$, now depends on the intensity of bank sheltering, as well as the agency's choice of input, a. Ceteris paribus, an increase in sheltering activity causes the agency's enforcement ratio to fall.

\section{A Pure Model of Competitive Regulation}

The primary feature of a competitive market for reserve requirement regulation is the assumption of a system of local regulatory agencies that compete with the central bank in setting and enforcing reserve requirements. As indicated above, I assume that there is only one local regulatory agency for each jurisdiction. The local sponsoring government can, however, replace the existing regulatory agency with a new agency at zero cost. This section develops a "pure" model in the sense that competition among the $n$ local governments to attract banks to their jurisdiction is perfect.

The competitive model also assumes that only central agency member banks hold central bank reserves. In contrast, each local agency mandates that reserves of its member institutions be in the form of non-interest-bearing liabilities provided by the private sector instead of the central bank. Local banks, therefore, are the class 2 banks of the previous section. Their deposits are not a source of central agency reserves. ${ }^{7}$

The central agency's problem of how to select the inflation rate, the reserve requirement, and its investment in enforcement inputs can be subdivided into smaller steps. Central to this problem is the determination of how competitive regulation at the local level constrains central bank actions. I first consider the budget the local government in a typical jurisdiction gives to its local regulatory agency. This budget allocation dictates the (maximum) level of local agency enforcement activity and allows banks to compute their profits when they choose local agency membership. The central bank then takes this profit condition into consideration in its decision problem. Specifically, the central bank maximizes net seigniorage subject to the constraint that profits promised its members are at least as great as profits those banks receive from local agency membership.

The assumption of perfect competition among local governments eliminates any discretion they might have in the budgetary process.

${ }^{7}$ Deposits at state agency banks generally had some effect on Federal Reserve base before 1980 (see supra, footnote 2). 


\section{Cato Journal}

Each local government will be driven by competition to grant its local agency a budget of zero. If, for example, a local government gives a budget that allows the regulatory agency to purchase some enforcement inputs, then bank profits in that jurisdiction will be lower than they potentially might be. This provides a neighboring local government with the opportunity to offer banks in its jurisdiction higher profits by granting its agency a lower enforcement budget. This budget-cutting process continues until budget appropriations in each jurisdiction equal zero. Ruling out subsidies to banks, local governments at this point have fully exploited their ability to attract banks to their jurisdiction.

The choice problem of the local regulatory agency follows trivially from this budgetary equilibrium. Without an enforcement budget, any attempt by the local agency to set a reserve requirement above the market level will be ignored by banks that are members of the local agency. Banks back their deposits with only the market level of reserves, and bank profits, designated as $p^{*}$, are the same as they would be in the absence of any formal regulatory structure.

Regulatory powers of the central bank are constrained by the condition that profits of its members be at least as great as $p^{*}$. Like the local regulatory agencies, therefore, the central bank is unable to enforce a reserve requirement higher than the market level. If the central bank tried to impose a statutory requirement higher than $\hat{k}$, no bank would take a central charter."

Since bank profits are identical with local or central agency membership, each bank flips a coin to solve its membership problem. On average, half the banks join the central agency and the remainder some local agency. The percentage of total financial sector liabilities that the central bank legally can require be backed by its base, $z$, equals $1 / 2$ in equilibrium.

Substituting $z=1 / 2, a=0$ (which implies $b=0$ ), and $k=\hat{k}$ into the central agency's scigniorage function (equation 2) results in

$$
S=\pi \hat{k}(J / 2) D(i)
$$

The central agency in this competitive regulatory setting has a decision problem that looks much like the traditional maximization problem depicted by equation (1). The main difference is that only a fraction ( $1 / 2)$ of banks are members of the central agency. As in the traditional case, seigniorage maximization implies that the central

${ }^{8}$ I assume that local (central) agency banks hold local (central) agency reserves in the absence of enforcement. Also, the market reserve ratio is the same for all banks, regardless of their affiliation. 
agency raises the inflation rate to the point where the inflation rate elasticity of money demand equals minus one.

One advantage of this competitive regulatory model, as compared with the traditional analysis, is that the reserve requirement is determined within the model. But the assumption of perfect competition among the $n$ local governments leads to the extreme conclusion that local regulatory agencies always set the reserve requirement at or below the market level. Competition at the local level forces the central agency to reduce its requirement accordingly.

Somewhat surprisingly, empirical work on the behavior of local agencies provides some support for the strong market implication. Alton Gilbert (1978, p. 19), for example, tested the effectiveness of state reserve requirements and concluded that "an overall assessment of results in this analysis supports the view that in general state reserve requirements are not effective."

Gilbert, however, found exceptions to this overall assessment. In states that do not allow banks to count cash items in process of collection as reserves, the reserve requirement influences nonmember bank behavior. More important, Fed membership across states is sensitive to the resources state agencies use to monitor and enforce requirements. These findings suggest not only that the effective reserve requirement exceeds the market level but also that requirements may differ across states.

The pure competitive model generates several other counterfactual conclusions. It implies that enforcement budgets can be no higher than zero and that central bank membership will be precisely one-half of the total number of banks. The following section reformulates the competitive interaction among local government sponsors in a way that allows (1) enforcement budgets greater than zero and, therefore, effective reserve requirements above the market level, (2) differences in statutory requirements between central and local agencies, (3) variations in effective requirements across localities, and (4) variations in central bank membership over time.

\section{Competitive Regulation with Local Government Budget-Setting Power}

Instead of assuming local government competition automatically drives enforcement budgets to zero, suppose local governments retain some budget-setting power. Each local government may use this power to induce local agency enforcement of a reserve requirement that is higher than the market requirement. This outcome presumes 
that over some range local governments prefer higher reserve requirements.

An interest group perspective suggests why a local government might have this preference. The local government may be responding to pressures from groups that benefit from higher local agency reserve requirements. For example, what if balances at specified correspondent banks and central government securities count as reserves? Reserve requirements then are a source of demand for these private and public obligations. Correspondent banks and the central government would have a common interest in lobbying (rewarding) the local government for using its budgetary authority in ways that lead to reserve requirement increases. ${ }^{9}$

The local government may favor higher reserve requirements for public interest considerations as well. Federal deposit insurance may induce banks to take too many risks in maximizing the value of their assets. In particular, banks may choose to reduce their reserve holdings below even market levels. This provides public-spirited local governments with the opportunity to use their budgetary powers to raise reserve requirements.

Whether interest group driven or public-spirited, a local government with budgetary power will grant a certain budget to its local agency with the expectation that the funds will be used to enforce an effective reserve requirement that is higher than the market level. However, because the local government directly observes only the statutory requirement, it cannot be sure that all the funds will be allocated strictly to production of a higher effective reserve requirement. The best the local government can do in these circumstances is to establish a target statutory requirement and rely on a contestable regulatory market to control local agency enforcement efforts.

What if a local agency used too few enforcement units and engaged in expense-preference behavior? With the appearance of any excess funds, outsiders would be prepared to take over management of the local regulatory agency. An efficient takeover market would ensure that enforcement activity would be raised to a level that cleared the market; that is, enforcement would increase to the point that exhausted excess funds. ${ }^{10}$

Bank profits will be lower when local agencies enforce requirements greater than market reserve requirements. Because local agency

\footnotetext{
${ }^{8}$ In addition, this section demonstrates that the central government's seigniorage extraction powers are enhanced with higher local agency reserve requirements,

${ }^{10}$ Without contestability, local governments must directly monitor agency shirking. Because such monitoring is not costless, some expense-preference behavior would be observed.
} 
membership is less attractive, constraints on central bank actions are not as tight. The central agency will be able to raise its reserve requirement above the market level and devote resources to enforcement.

Consider the central bank decision problem when local agencies throughout the federal region receive identical enforcement budgets and set identical statutory reserve requirements (higher than $\hat{k}$ ). Although local bank profits will be the same in each jurisdiction, the central bank does not have to set its own control variables at precisely the levels established by the local regulatory agencies. It need only choose a reserve requirement and enforcement input combination such that the profits a bank receives from central bank membership equal the (now lower) profits a bank receives from local agency membership. The central agency may trade off a high (low) statutory reserve requirement for a low (high) level of enforcement activity.

With differential levels of local enforcement, profits of local agency members will differ across localities. The central bank now has an additional decision-making margin. Since there is no common local bank profit level, the central bank may choose to provide its members with either relatively low or high profits. ${ }^{11}$ By choosing low levels of enforcement activity and low statutory reserve requirements, the central agency can induce banks in most states (that is, those with high effective reserve requirements) to choose central agency membership. Incrementally higher central bank activity levels and reserve requirements cause membership losses in marginal states. Instead of central bank membership being an all-or-nothing proposition, membership steadily declines as the effective reserve requirement rises. $^{12}$

The extended competitive model avoids the factual anomalies associated with the pure model. Generally, the extended model predicts that both local and central regulatory agencies will enforce reserve requirements. To the extent that enforcement budgets differ among states, effective reserve requirements also differ. Given a continuum of local agency effective reserve requirements, the central agency can vary its effective reserve requirement within this range.

\section{Monopoly Reserve Requirement Regulation}

This section replaces competitive regulation with a setting suggested by the Depository Institutions Deregulation and Monetary

\footnotetext{
"The central bank sets uniform statutory reserve requirements and enforcement activity levels across all states.

${ }^{12}$ In terms of seigniorage equation (2), $z$ is now a function of activity level $a$ and statutory requirement $k$.
} 


\section{Cato JoURnal}

Control Act of 1980. In particular, I assume here that the central agency has statutory authority to require all banks to hold reserves in the form of central bank-produced base. The central agency not only sets the reserve requirement for all banks but also is the only enforcement agency. Local agencies no longer monitor local bank compliance with reserve requirements.

The seigniorage function of a central bank that has a monopoly in setting and enforcing reserve requirements becomes

$$
S=\pi[b k+(1-b) \hat{k}] D(i)-C(a) .
$$

The fraction, $z$, of total financial sector liabilities that the central bank legally can require be backed by its base automatically rises to one. Note also that the central bank no longer is constrained by a financial institution profit condition. Because the central bank regulates all policy variables (including reserve requirements for nonmembers), bank profits-and, therefore, central bank seigniorage-are not affected by the membership decision. In this pure monopoly setting, the central bank does not worry that the profits of its members may be lower than those of nonmembers. ${ }^{13}$

The absence of a bank profit constraint, however, does not imply that the central bank wants to raise reserve requirements and enforcement activities as high as possible. Increases in statutory reserve requirements and enforcement activities have negative as well as positive effects on central bank seigniorage. An increase in the reserve r'equirement, for example, increases seigniorage for a given enforcement ratio, $b$. But this positive effect will be at least partially offset by the increased bank-sheltering activity induced by the reserve requirement change. Similarly, although an increase in the amount of resources invested in enforcement activities raises seigniorage by increasing the enforcement ratio, it also raises enforcement costs. The monopoly central bank will be motivated to raise each of these control variables to the point where marginal benefits just equal marginal costs.

\section{Comparison of Competitive and Monopoly Reserve Requirement Regulations}

If local governments are modeled as having no budget-setting power, then the contrast between competitive and monopoly reserve

\footnotetext{
${ }^{13}$ Throughout the paper, I assume that banking agencies regulate only reserve requirements. This assumption is not descriptive of the U.S. regulatory market. After passage of the Monetary Control Act, for example, the relative attractiveness of Fed and state agency membership still depends on differences in other regulatory policies.
} 
requirement regulations is most striking. Even if the monopoly regulator does not enforce requirements higher than market reserve requirements, a comparison of equation (3) (where seigniorage becomes $\pi \hat{k}(1 / 2) D$ ) with equation (4) (where seigniorage becomes $\pi \hat{k} D$ ) indicates that monopoly seigniorage will be twice as high as competitive seigniorage. More generally, this comparison understates the seigniorage difference because granting the central bank monopoly status transforms it from a "price taker," where it has no discretion over reserve requirement policy variables, into a "price setter." The effective reserve requirement will be raised from its market level to its monopoly level.

The ability of local governments to set their own budgets relaxes the price-taker constraints on the central bank. The central bank's decision problem in this modified competitive setting does not differ qualitatively from its problem in the pure monopoly setting. In both settings the central bank must search for policy instrument values that maximize seigniorage.

Under certain circumstances, the central bank's policy decisions will be identical in the competitive and monopoly settings. Consider the special case wherein all local governments happen to grant their local agencies uniformly "large" budgets. Bank profits from local agency membership will be correspondingly low. Profits may be so low that a central bank, acting as an unconstrained monopoly regulator, would choose to reduce them no lower. Because this type of competition places no effective constraint on central bank behavior, the central bank chooses the same reserve requirement and enforcement levels regardless of the regulatory structure.

Local governments generally do not grant such large enforcement budgets. Therefore, the bank profit constraint the central bank faces in the competitive setting usually will be binding. Making the central bank a monopoly regulator eliminates this constraint and induces it to raise its reserve requirement and enforcement activities above the (modified) competitive solution.

As with any market, monopoly in the market for reserve requirement regulations provides the producer with readily identifiable benefits. With respect both to statutory requirements and enforcement levels, the monopoly setting allows the central bank to raise the reserve requirement tax on banks. The monopolist's ability to exploit its position will be constrained by the opportunities banks have to evade reserve requirement regulations. Still, seigniorage at any inflation rate will be higher in the monopoly setting as compared with either the pure or modified competitive setting. 


\section{Conclusion}

Economists have long known that reserve requirements create a demand for central bank base money. However, they have not formally acknowledged that resources must be invested in enforcement activities for these requirements to be effective. Earlier approaches tended to view the central bank as an automaton-like agency that costlessly identified bank liabilities as reservable. According to this view, the reserve requirement itself was either set by an unconstrained central bank or by unspecified political forces.

This paper has outlined a model of a seigniorage-maximizing central bank that controls its base rate of production, but whose ability to set and enforce reserve requirements may be constrained by competition from local regulatory agencies. The interaction between local governments and their local regulatory agencies helps define the political forces that constrain central bank actions. Several predictions emerge from this perspective.

First, the reserve requirement generally will not be set at the market level. The market solution emerges only in the special case where competition is so tight that local governments have no budgetsetting powers. More generally, the local government provides its local regulatory agency with the budgetary inducement to expend some resources in enforcing a reserve requirement that is above the market benchmark.

Second, the reserve requirement and enforcement decisions of local agencies constrain the central bank's choice of policy variables in the competitive setting. Central bank regulations cannot leave a member bank with lower profits than that bank receives with membership in a local agency. If local agency regulations become less stringent, perhaps because of a tax revolt at the regional level, then the central bank must respond by a combination of reserve requirement and enforcement activity cuts. Overall, the regulatory model suggests that political "market" constraints, and not exogenous macroeconomic considerations, drive the central bank's reserve requirement decisions.

In the post-World War II period, reserve requirements of state agencies and the Federal Reserve System generally declined. State banking regulations, however, became progressively less stringent compared with Fed reserve requirement regulations. As a result, the Fed experienced a steady membership decline during the 1960s and 1970s. Continuation of this trend threatened to force the Federal Reserve out of the reserve requirement regulatory market. Partially in reaction to this threat, Congress passed the Depository Institutions Deregulation and Monetary Control Act of 1980. 
The act changed the rules of the game by relaxing constraints on decision makers at the Fed. By giving the Fed the authority to impose reserve requirements on deposit liabilities of all financial institutions, the act eliminated local agencies as regulatory competitors, allowing the Fed to increase the stringency of its reserve requirement regulations and thereby extract more wealth through money production.

The model outlined in this paper does not predict that the Fed will immediately act as a profit-maximizing monopolist with passage of the Monetary Control Act. In particular, the Fed is a bureaucratic agency that does not have residual claimant rights to seigniorage. Furthermore, instead of allowing the Fed to set initial reserve requirement levels, the act directly defined new requirements. ${ }^{14}$

The Act does grant the Fed explicit powers to change reserve requirements in the future. The prediction of more stringent reserve requirement regulations, therefore, illustrates the long-run tendencies of a monetary authority that no longer is constrained by competition from other agencies in this regulatory market. In this sense the Monetary Control Act can be interpreted as a change in the nation's monetary constitution that enhances the wealth-extraction powers of the central government.

\section{References}

Cacy, J. A., and Winningham, Scott. "Reserve Requirements under the Depository Institutions Deregulation and Monetary Control Act of 1980." In Issues in Monetary Policy, vol. 2, pp. 68-81. Kansas City, Mo.: Federal Reserve Bank of Kansas City, 1982.

Dwyer, Gerald P., and Saving, Thomas R. "Government Revenue from Money Creation with Government and Private Money." Journal of Monetary Economics (March I986): 239-50.

Friedman, Milton. "Discussion of the Inflationary Gap," In Essays in Positive Economics, pp. 251-62. Chicago: University of Chicago Press, 1953.

Gilbert, Alton R. "Effectiveness of State Reserve Requirements." Federal Reserve Bank of St. Louis Review (September 1978): 16-28.

Gilbert, Alton R, and Lovati, Jean M. "Bank Reserve Requirements and Their Enforcement: A Comparison across States." Federal Reserve Bank of St. Louis Review (March 1978): 22-33.

Goodfriend, Marvin, and Hargraves, Monica. "A Historical Assessment of the Rationales and Functions of Reserve Requirements." Federal Reserve Bank of Richmond 1982 Annual Report, pp. 5-23.

\footnotetext{
${ }^{14}$ Although the act lowered requirements for members of the Fed and raised them for nonmembers, on balance the reserve requirement burden increased (Cacy and Winningham 1982).
} 


\section{Cato journal}

Greenbaum, Stuart. "Legal Reserve Requirements: A Case Study in Bank Regulation." Journal of Bank Research (Spring 1983): 59-69.

Hester, Donald D. "Innovations and Monetary Control." In Brookings Papers on Economic Activity, pp. 141-89, Edited by William Brainard and George Perry. Washington, D.C.: Brookings Institution, 1981.

Kane, Edward. "Accelerating Inflation, Technological Innovation, and the Decreasing Effectiveness of Banking Regulation." Journal of Finance 36 (1981a): 355-67.

Kane, Edward, "Regulatory Policy for a Changing Financial Services Industry." In Technological Innovation, Regulation, and the Monetary Economy, pp. 125-43. Edited by Colin Lawrence and Robert P, Shay. Cambridge, Mass.: Ballinger, 1981b.

Kane, Edward. "Changes in the Provision of Correspondent-Banking Services and the Role of Federal Reserve Banks under the DIDMC Act." In Monetary Regimes and Protectionism, pp. 93-126. Edited by Karl Brunner and Allan H. Meltzer. Amsterdam: North-Holland, 1982. 


\section{Federal Reserve Interest Rate SMOOTHING Marvin Goodfriend}

Mark Toma's interesting paper on the theory of reserve requirement regulations explains such requirements as resulting from a government revenue-raising motive. I do not intend to address the details of Toma's argument or to comment directly on the plausibility of the view that reserve requirements are simply a tax. Nor will I discuss the specifics of his public choice theory explaining the structure of reserve requirements. Instead, this article focuses on a related topic, that of Federal Reserve interest rate smoothing. As shall become clear, the discussion here supports Toma's hunch on how to explain reserve requirements.

A discussion of interest rate smoothing is appropriate for a number of reasons. In recent years the theoretical feasibility of interest rate smoothing has been demonstrated in coherent rational expectations models. (See, for example, McCallum 1986 and Goodfriend 1987a.) This development has paved the way for sensibly interpreting the comments of Fed watchers who persistently characterize Federal Reserve policy as choosing the level of short-term interest rates. It also makes sense of the extensive institutional evidence that the Fed can and has smoothed interest rates throughout its history. (See Goodfriend 1987b.) In addition, empirical work by Miron (1986), Mankiw and Miron (1986), and Barro (1987) provides evidence of both seasonal and cyclical Fed interest rate smoothing. Giving interest rate smoothing a central place in thinking about monetary policy thereby reconciles analytical, financial market, institutional, and empirical

Cato Journal, Vol. 7, No. 3 (Winter 1988), Copyright $\odot$ Cato Institute. All rights reserved.

The author is Vice President and Reseach Economist at the Federal Reserve Bank of Richmond. The views expressed here do not necessarily reflect those of the Federal Reserve Bank of Richmond. The paper was written while the author was Visiting Associate Professor at the University of Rochester. 


\section{Cato Journal}

evidence. The attractiveness of the interest rate smoothing view of monetary policy comes in part from this reconciliation.

As discussed below, the fact that the Fed has employed interest rate smoothing throughout its history implies that the standard rationale for reserve requirements-that they are necessary for monetary control-has been highly misleading. The interest rate smoothing characterization of monetary policy thereby provides indirect support that reserve requirements have functioned exclusively as a tax. This supports Toma's view that the structure of reserve requirements must be explained as a government revenue-maximizing motive.

In addition, pursuing the analytical and empirical implications of interest rate smoothing seems to be a promising way of developing a better understanding of monetary policy as it is actually conducted. In other words, it provides a realistic way of pursuing the positive theory of monetary policy. Historically, economists have emphasized the normative aspects of monetary policy, suggesting models of what the Fed ought to do, but they have found their advice largely ignored. Perhaps by using the interest rate smoothing view, economists can better understand the objectives and constraints facing the Fed so that policy advice can be made more relevant, tailored better to the realities of central banking, and have a better chance of being implemented.

\section{How Interest Rate Smoothing Works}

An oral tradition in monetary economics holds that the central bank cannot control nominal interest rates directly. For example, it asserts that the central bank cannot peg the nominal interest rate because doing so would make the price level unstable or indeterminant. This view dates back at least to Wicksell $(1898,1905)$. It was echoed by Friedman (1968) and received a more formal restatement in Sargent and Wallace (1975). This view, however, has been successfully challenged in recent years. First, McCallum (1981) showed that a monetary authority could run an adjustable nominal interest rate peg and generate a stable, determinate price level. The stability and determinacy of the price level under an absolute nominal interest rate peg was demonstrated by Dotsey and King (1983) and Canzoneri, Henderson, and Rogoff(1983). McCallum (1986) related these new developments to the real bills doctrine. Goodfriend (1987a) discussed the definitions, mechanics, and implications of interest rate smoothing in a positive theory of central bank behavior. It must be emphasized that these papers explain the feasibility of price level determinacy with nominal interest rate smoothing by the monetary authority. 
Whether the monetary authority can smooth real interest rates is a separate and more controversial matter. This discussion assumes that the monetary authority cannot influence real interest rates.

To understand the mechanics of nominal interest rate smoothing, consider Goodfriend's (1987a) model, which has three basic equations. First, it has a money demand function. Second, it has a Fisher equation relating the nominal interest rate to an ex ante real interest rate component plus an expected inflation component. It is helpful to conceive of the Fisher relation as an arbitrage condition equalizing expected real yields on nominal bonds with the real interest rate that clears the economywide goods market. Third, the model has a money supply rule that explains how the central bank generates the nominal money stock. The details of the money supply rule are unimportant for this discussion. What is important is that at each point in time, the money supply rule allows the public to form a determinate expectation of the future nominal money stock.

Interest rate smoothing works as follows. The money supply rule pins down the expected future nominal money stock each period. This, together with expected future real demand for money, implies an expected future price level. Suppose the central bank is pegging the nominal interest rate. The market sets the real expected yield on nominal debt equal to the goods market clearing real rate by bidding the current price level to the point where the pegged nominal rate less expected inflation just equals the required real interest rate.

A key feature of this equilibrium is that the current price level is determined by working backward from expectations about the future price level, through the expected inflation necessary to convert the nominal interest rate peg into the required real yield. Current nominal money growth, therefore, does not cause inflation under interest rate targeting. The current price level is determined by the level of the nominal interest rate peg, together with the goods market clearing real interest rate and future expected nominal money supply and demand.

Suppose the money supply rule were to pin down the future price level at a fixed target so that the price level were stationary. In this case, nominal interest rate smoothing would make the real interest rate shock move the current price level around. That is, the expected inflation or deflation required to convert the real yield on nominal debt into the required ex ante real rate would be achieved by bumping around the current price level.

In practice, central banks are uncomfortable allowing the current price level to be erratic. Long-term nominally denominated contracts in credit and labor markets may allow surprise price level movements 


\section{Cato Jounnal}

to have potentially destabilizing effects. Goodfriend (1987a) has shown that a central bank wishing to minimize price level forecast error and smooth nominal interest rates can create the necessary inflation or deflation by moving the expected future price level around instead. Such a policy, however, makes both the price level nonstationary and the money stock exhibit "base drift." (See Goodfriend 1987b for a discussion of base drift.) It converts temporary real interest rate movements into permanent jumps in the money stock and price level. As the forecast horizon recedes, price level and money stock forecast error variance go to infinity. In this sense, interest rate smoothing creates macroeconomic instability. It appears that interest rate smoothing is a policy widely followed by world central banks because they believe that the financial stability it buys is worth the cost in increased price level instability. It remains unclear to me, however, whether this often-heard rationale for interest rate smoothing accords with its actual explanation. We need much future work on this question.

Finally, in this section, I want to apply the theory of interest rate smoothing to explain why reserve requirements are unnecessary for monetary control. The standard view is that reserve requirements are useful in enabling the central bank to better control the money stock. (See Friedman 1960, p. 50.) In this view, reserve requirements operate by stabilizing the money multiplier, thereby allowing the central bank to control bank deposit money with its total reserve instrument. But under interest rate smoothing as practiced by the Federal Reserve, the money multiplier does not play a causal role in nominal money stock or price level determination. Under interest rate smoothing, the current price level is determined by the chosen level of the nominal interest rate, the goods market clearing real interest rate, and the expected future price level. Current-period money demand, depending, of course, on the current price level, is accommodated by the central bank at the chosen current nominal interest rate. Reserve requirements simply help determine the quantity of monetary base that the central bank must supply currently to provide that accommodation. But reserve requirements do not help determine the money stock.

\section{Institutional Means of Interest Rate Smoothing}

The Federal Reserve has achieved its interest rate targets over the years in varied and somewhat complicated ways (Goodfriend 1987b). In the 1920 s the Fed used relatively little nonprice rationing at the discount window. It forced the banking system to obtain a portion of monetary base demanded by borrowing at the window. But because 
there was little nonprice rationing, the discount rate, roughly speaking, provided a ceiling for other interest rates. The discount rate was raised and lowered to adjust the level of short-term interest rates, with appropriate adjustments to nonborrowed reserves so that banks were continually induced to borrow some monetary base at the window.

During most of the $1930 \mathrm{~s}$, the discount rate was above market rates, so borrowing at the window was negligible. From 1933 to the end of the decade, the Fed held its portfolio of government securities essentially constant. The Fed, therefore, could not be construed as smoothing interest rates during this period. Interest rates, however, were extremely low, less than 1 percent, and were more or less smoothed any way because they were near their lower bound of zero. So there would have been no need for the Fed actively to smooth interest rates. Later, in the 1940 s, the Fed smoothed interest rates as part of its government security price pegging policy during and after World War II.

A procedure similar to that used in the 1920 s was also used in the 1950s and 1960s after the Treasury-Federal Reserve Accord. The difference was that the target for borrowed reserves was varied more often to affect slight changes in the level of rates without always changing the discount rate. In the 1970s the Federal Reserve used an adjustable federal funds rate peg by establishing bands of 50 basis points, on average, within which it would keep the funds rate by appropriate open market operations whenever the limits of the band were hit.

The Fed's move to reserve targeting in October 1979 did not mean abandoning interest rate smoothing. Because reserve requirements were lagged (until February 1984), reserve demand was predetermined within a given reserve statement week. Hence, by choosing a nonborrowed reserve target in a given week, once again the Fed used a procedure whereby it essentially chose a quantity of reserves the banks would have to borrow at the discount window. Given Fed nonprice rationing, the demand for discount window borrowing is a function of the spread between the federal funds rate and the discount rate. By choosing the volume of forced borrowing together with the discount rate, the Fed in effect selected a level of the federal funds rate on a week-by-week basis. This procedure amounted to a kind of noisy interest rate smoothing because of the unpredictable variability in the demand schedule for discount window borrowing. Moreover, it was one in which reserve requirements played an inessential role; an identical path for the nominal interest rate could have been produced by choosing a level for the funds rate directly. Even 


\section{Cato Journal}

since reserve requirements were made contemporaneous in February 1984, ostensibly to improve monetary control, the Fed has continued to target borrowed reserves or the federal funds rate, so the structure of reserve requirements has remained irrelevant to monetary control.

\section{Empirical Evidence on Interest Rate Smoothing}

I referred in the introduction to recent empirical evidence of interest rate smoothing. Miron (1986) has shown that the Fed removed a pronounced seasonal fluctuation in the nominal interest rate that ranged about 6 percentage points from 1890 to 1914 . Of course, earlier authors such as Friedman and Schwartz (1963) recognized this, Mankiw and Miron (1986) cannot reject the view that the short-term interest rate is a random walk after the founding of the Fed, but not before. They suggest their finding represents interest rate smoothing behavior on the part of the Fed.

Barro (1987) used Goodfriend's (1987a) model of interest rate smoothing with a public finance view of the Fed's nominal interest rate target. Goodfriend assumed a constant nominal interest rate target to illustrate the mechanics and feasibility of interest rate smoothing. His simplifying assumptions made the nominal interest rate a serially uncorrelated white noise process. As mentioned above, Mankiw and Miron found it to be approximately a random walk. Barro appended a random walk nominal interest rate target generating equation to Goodfriend's model. In an earlier paper, Barro (1979) showed that optimal tax policy involves the government making the tax rate a random walk. Pointing out that the nominal interest rate is the tax rate on the monetary base, Barro justified his nominal rate random walk equation as optimal tax policy. His justification for the random walk interest rate target follows from and is empirically substantiated somewhat by Mankiw (1986).

Kimbrough's (1986) argument, however, weakens the optimal tax policy rationale. He showed that if money is explicitly modeled as an intermediate good that helps to affect the conversion of scarce resources into consumption goods, then it is not optimal to use an inflation tax to help generate revenue. Instead, optimal taxation calls for adopting the optimum quantity of money rule in which the government generates a rate of deflation that makes the nominal interest rate zero.

Nonetheless, with some additional modifications, Barro derives and tests joint restrictions on the inflation and monetary base generating processes implied by Goodfriend's model coupled with the 
random walk nominal interest rate target generating process. Barro's results are for the period 1890 to 1985 . He rejects the model for the period before the establishment of the Fed, finds mixed results for the interwar period, but cannot reject the model for the post-World War II period. In short, his results are encouraging though preliminary,

\section{Conclusion}

This paper has argued that nominal interest rate smoothing has been an important feature of monetary policy as practiced by the Federal Reserve. It has drawn on recent theoretical, institutional, and empirical work to make the point. By documenting the interest rate smoothing view and by pointing out that reserve requirements serve no monetary policy purpose under it, the discussion has provided indirect support for the view that reserve requirements must be explained as a tax.

\section{References}

Barro, Robert. "On the Determination of the Public Debt." Journal of Political Economy (October 1979): 940-71.

Barro, Robert. "Interest Rate Smoothing." Unpublished manuscript. University of Rochester, February 1987.

Canzoneri, Matthew; Henderson, Dale; and Rogoff, Kenneth. "The Information Content of the Interest Rate and Optimal Monetary Policy." Quarterly Journal of Economics (November 1983): 545-66.

Dotsey, Michael, and King, Robert. "Monetary Instruments and Policy Rules in a Rational Expectations Environment."Journal of Monetary Economics (September 1983): 357-82.

Friedman, Milton. A Program for Monetary Stability. New York: Fordham University Press, 1960.

Friedman, Milton. "The Role of Monetary Policy." American Economic Review (March 1968): 1-17.

Friedman, Milton, and Schwartz, Anna. A Monetary History of the United States. Princeton, N.J.: Princeton University Press, 1963.

Goodfriend, Marvin. "Interest Rate Smoothing and Price Level TrendStationarity." Journal of Monetary Economics (May 1987a).

Goodfriend, Marvin. Monetary Policy in Practice. Federal Reserve Bank of Richmond, 1987b.

Kimbrough, Kent. "The Optimum Quantity of Money Rule in the Theory of Public Finance." Journal of Monetary Economics (November 1986): 27784.

Mankiw, Gregory, "The Optimal Collection of Seigniorage: Theory and Evidence." Unpublished manuscript. Harvard University, November 1986.

Mankiw, Gregory, and Miron, Jeffrey. "The Changing Behavior of the Term Structure of Interest Rates." Quarterly Journal of Economics (May 1986): 211-28. 


\section{Cato Journal}

McCallum, Bennett. "Price Level Determinacy with an Interest Rate Policy Rule and Rational Expectations." Journal of Monetary Economics (November 1981): 319-29.

McCallum, Benrett. "Some Issues Concerning Interest Rate Pegging, Price Level Determinacy, and the Real Bills Doctrine." Journal of Monetary Economics (January 1986): 135-60.

Miron, Jeffrey. "Financial Prices, the Sensonality of the Nominal Interest Rate, and the Founding of the Fed." American Economic Review (March 1986): $125-40$.

Sargent, Thomas, and Wallace, Neil. "Rational Expectations, the Optimal Monetary Instrument, and the Optimal Money Supply Rule." Journal of Political Economy (April 1975): 241-54.

Wicksell, Knut. Interest and Prices. 1898. Translated by R. F. Kahn. London: Macmillan, 1936.

Wicksell, Knut. Lectures on Political Economy, Vol, 2, 1905. Translated by Lionel Robbins. London: Routledge and Kegan Paul, 1935. 